\title{
利用者属性に着目したコミュニティバス利用者満足度と利用頻度向上施策に関する研究*
}

\section{Improvement of operation on community bus considering user attributes*}

\author{
棉原充輝**・松本幸正 $* * * \cdot$ 高橋政稔**** \\ By Mitsuteru SAKAKIBARA** • Yukimasa MATSUMOTO*** • Masami TAKAHASHI****
}

1. はじめに

現在 , 住民モビリティの確保や交通空白地域の解消， 公共施設への交通手段の提供などの目的から, 主に自治 体が主体となりコミュニティバスが全国的に運行されて いる.最近では，多樣化する住民二ーズに対し，コミュ ニティバスのサービス内容を拡充する市町村も多く , 運 行経費力渭加している自治体も多い。

しかしながら，コミュニティバス事業において, 適 切な事業評価を実施している自治体は少ない1). 平成19 年度では, 基本的な評価指標の一つである乗降データを 把握している中部圈の自治体は, 全体の $55 \%$ となってい る.一方で, 利用者満足度を調査している市町村は, わ ずか18\%でしかない．また，経費に対する運賃収入等の 事業性について調査している市町村は，30\%であるなど， 多くの自治体においてコミュニティバス事業に対する事 業評価は適切に行われているとは言い難し状況にある . このような中 , 今後もコミュニティバスの果たす役割は 増大し，運行主体に対する期待も高まっていくと考えら れ，コミュニティバス整備やサービス改善にあたって利 用者意識を把握・分析するなど, 的確な評価を行うこと が重要であるといえる .

コミュニティバスの評価について，さまざまな研究 か行われている.樋口ら 2は, コミュニティバス運行の 現状と住民評価を分析し, コミュニティバスの総合満足 度に「運行間融」,「ルート」，「運行時間帯」か影響 を与えること示している.コミュニティバスの運行サー ビス変更に伴う利用者意識の変化を捉えた研究例として， 板谷ら 3は, 定期的にアンケート等の評価を行い, 路線 の見直しを行いつつ試験運行を続けている尾張旭市を事 例に, 利用者意識の経年変化を捉え, 運行開始後の評価 や見直しの方策について考察している.これに加え，コ

*キーワーズ : 公共交通運用, 公共交通計画, 地区交通計画, 交通意識分析

** 正会員 , 修(工), 名古屋市交通局

***正会員, 博(工), 名城大学理工学部建設システム工学科

(名古屋市天白区塩金口一丁目501番地，

TEL:052-832-1151 FAX:052-832-1178 )

****正会員, 博(工), 名城大学理工学部環境倉造学科
ミュニティバス利用者にはさまざまな属性があることか ら，属性によって異なる利用形態や利用者意識を捉える ことも重要である.利用者属性を考慮した研究例として， 井上ら 4)は, 有料利用と無料利用, 民営バス停圏内外別 などの属性別にコミュニティバス利用実態と利用者意識 の違いを捉えている .

このように, 研究上の評価としては数多くの成果が 得られており，運行主体に向けて運営方法などを解説し たノウハウ本も出版されているが 5) 6), 利用者属性ごと のうさわしい運行のあり方まては示されていない .

兴の理由として，コミュニティバスに関する調査は， 運行主体ごとに個別に行われており，共通の知見を得る ことか難しいことが考えられる.コミュニティバスの利 用形態は，運行サービスや地域特性に大きく左右される ことから，本来は全てのコミュニティバスを対象に個別 に調査力行われることか望ましい，しかしながら，財政 状況などの理由により, 自治体が単独で利用実態や利用 者意識などを捉えることは困難である場合も多く，兴の 際には，さらに運行サービスを見直すことさえも難しい， そのため, 運行サービスの異なる自治体間においても共 通する，利用者から見た望ましいコミュニティバスのあ り方を検討し，各地の運行見直しに資する知見を得る必 要がある.

運行形態の異なる自治体での利用者意識の差異を捉 えた研究例として, 榊原ら ニティバス利用者意識調査から運行サービスに対する利 用者ニーズの差異を捉え，高齡者と非高齢者の満足度向 上施策を示している.また，運行サービスと利用者総合 満足度の相関関係を捉えた研究例として, 井上 8)らは, 運行サービスの変更前後て調査を実施し, 改善のあった 運行サービスに対する評価が向上するとともに，総合満 足度も向上したことを明らかにしている.このような運 行サービスの改善による利用者の総合満足度向上によっ て , 現利用者が他の交通手段へと逸走することを防ぐこ とができると考えられる．

また一般的に，総合満足度の向上は，利用頻度を高 めることにもつながると考えられている.仮に総合満足 度と利用頻度に相関関係がある場合は, 総合満足度の向 上を目指せばよく，光の結果，利用頻度も向上するとい 
う効果が見込まれる .もし相関関係力認められない場合 は，光れ光れ別の向上策の検討を要することになり，総 合満足度や利用頻度に影響する要因を把握することは， バスサービスの見直しにとって不可欠である .

乥こで本研究では, より良いコミュニティバスの運 行サービスと運行方針の検討に資する知見を得ることを 目的とし, 愛知県内のほほ同じ地勢の 3 市町て運行さ れているコミュニティバスを対象として，利用者意識調 査を実施した .この結果から, はじめに, 利用者の総合 満足度と利用頻度の関係について明らかにする . 次に， 総合満足度 ・利用頻度と利用形態・運行サービスの関係 について示す.ここから得られた指標を用いて, 経路の 変更や運行本数の拡大などによって, 各運行サービス項 目か改善された場合の評価を想定したシナリオ分析を行 い, 属性による改善効果の差異を明らかにする .

\section{2. 研究対象地域と調査の概要}

\section{(1) 研究対象地域とコミュニティバスの概要}

本研究では, 運行サービスの異なるコミュニティバ スを乥れ運行している, 隣接する愛知県日進市, 長 久手町, 東郷町を対象として分析を進める. 平成 17 年 における対象市町の概要を表 1 に示す. 人口密度, 各 市町の高齢者割合 , 男性割合 , 就業者割合ともに , 大き な違いはない．

日進市は, 名古屋市に近い西部を中心に宅地化が進 んだため, 街区か集中し, 人口密度力比較的高い, 今後 も全国屈指の高い人口増加率が見込まれている.市内南 部には, 「赤池駅」，「日進駅」，「米野木駅」の3鉄 道駅がある。

長久手町は, 近年, 日進市と共に名古屋市のベッド タウンとして人口か急増した . 公共交通網としては, 日 本で初の実用的な磁気浮上式鉄道の愛知高速交通東部丘 陵線 (リニモ) が運行されている.また, 名古屋市東部 の地下鉄東山線終点駅である「藤が丘駅」か比較的近く， 多くの住民に利用されている。

東郷町は, 名古屋のベットタウンとして発展する一 方, 多くの自然を残している.公共交通網としては, 鉄 道は通っておらず, 町北部に隣接する日進市南部の「赤 池駅」，「日進駅」へ向かう民営バスが運行されている．

各市町ともに,「交通空白地帯の解消」,「公共施 設への利便性向上」，「交通弱者の社会参加促進」など を目的として，コミュニティバスが運行されている．

コミュティバスの路線図を図 1 に, 概要を表 2 に示 す . 対象とするコミュニティバスは，すべて公共施設を 発着点とし, 循環する経路を設定しているが, 弚の循環 形態に差異がある . 日進市て運行されている「くるりん ばす」と，長久手町て運行されている「N-バス」では，
表 1 対象市町の概要

\begin{tabular}{c||c|c|c}
\multicolumn{1}{l|}{} & 日進市 & 長久手町 & 東郷町 \\
\hline \hline 面積 & $34.90 \mathrm{~km}^{2}$ & $21.54 \mathrm{~km}^{2}$ & $18.03 \mathrm{~km}^{2}$ \\
\hline 人口 & 77,888 人 & 45,562 人 & 40,545 人 \\
\hline 高龄者割哈 & $13.6 \%$ & $11.9 \%$ & $13.8 \%$ \\
\hline 男性割合 & $50.5 \%$ & $51.2 \%$ & $50.5 \%$ \\
\hline 就業者割恰 & $48.5 \%$ & $49.4 \%$ & $50.7 \%$ \\
\hline
\end{tabular}

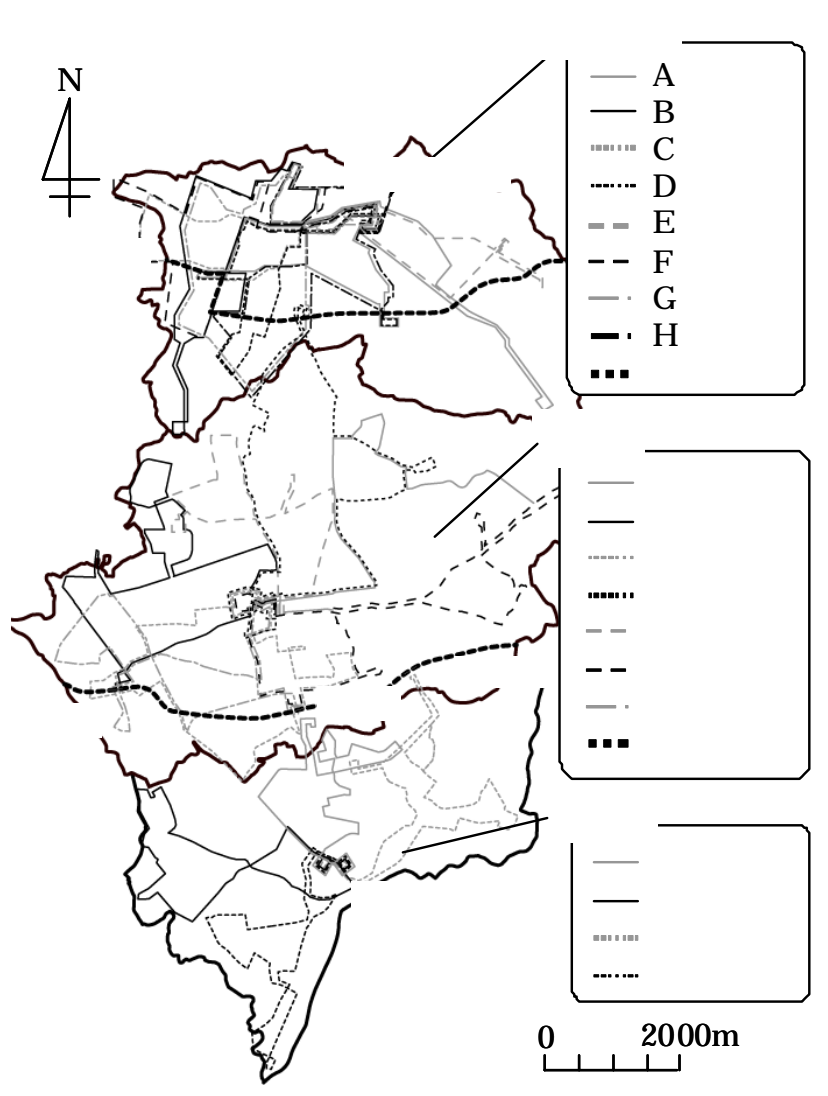

図 1 対象市町とコミュニティバス路線図

表 2 対象コミュニティバス概要

\begin{tabular}{|c|c|c|c|}
\hline & 日進市 & 長久手町 & 東郷町 \\
\hline & くるりんばす & $\mathrm{N}$-バス & じゅんかい君 \\
\hline コース & 7コース & 8 コース & 4 コース \\
\hline 起発着点 & 市役所 & $\begin{array}{c}\text { 役場 } \\
\text { 福祉の家 }\end{array}$ & $\begin{array}{c}\text { いこまい館 } \\
\text { (役場) }\end{array}$ \\
\hline 循環形態 & 一方向 & 一方向 & 双方向 \\
\hline バス停 & 136箇所 & 116箇所 & 187箇所 \\
\hline 便数/コース & 11 便/コース & 4 7便/コース & 12便/コース \\
\hline 運行時間帯 & $7: 10 \sim 18: 20$ & 7:30 19:41 & 7:05 19:02 \\
\hline 運行間隔 & 約 1 時間毎 & 約 1 3時間毎 & 約 2 時間毎 \\
\hline 65 歳未満 & 100円 & 100円 & 100円 \\
\hline 賃 高齢者 & 100 円 & 無料 & 無料 \\
\hline 乗換割引 & 1 回無料 & なし & なし \\
\hline 高龄者定期券 & 1000 円/月 & なし & なし \\
\hline 本格運行開始 & 平成 11 年 & 平成 10 年 & 平成 12 年 \\
\hline
\end{tabular}


一方向のみの運行であるのに対し，東郷町て運行されて いる「じゅんかい君」は両方向に交互に運行している． これにより，「じゅんかい君」では 1 コースあたり約 1 時間毎の運行か確保されている．「くるりんばす」も 1 コースあたり約 1 時間毎の運行である. しかし $「 \mathrm{~N}$ - バ ス」では最大で 3 時間 27 分も運行間䛿開くことがあ るなど, 便数, 運行間融はコースによって大きく異なっ ている.運賃は各バスともに非高齢者では一乗車 100 円であるが，高齢者は「くるりんばす」のみ有料となっ ており，1 ヶ月定期券力発売されている .

\section{（2）利用者意識調査の概要}

本研究では, 「くるりんばす」,「N-バス」，「じ ゆんかい君」利用者を対象に, 運行サービスに対する評 価などを捉えるための利用者意識調査を行った。 調査は バス車内でアンケートを配布し, 後日, 郵送回収した . 各コミュニティバスの調査日と配布部数, 有効回収部数 を表3に示す．

本調査のアンケートは前半と後半の 2 部構成となっ ている.アンケート項目は, 前半か浰用者の属性と交通 行動など, 後半がコミュニティバスに対する満足度と運 行目的の認知度などである。

\section{3. 利用者満足度と利用頻度の相関関係}

本研究では, コミュニティバスの評価指標として， 利用者の総合満足度と利用頻度に着目する . 一般的に， 総合満足度と利用頻度には関係性があり, 運行サービス の改善などによって総合満足度を向上させることは, 利 用頻度を高めることにもつながると考えられている.は じめに，これらの相関関係について示す．

調査では, 利用者に総合満足度として5段階て評価し てもらった . また , 同時に利用実態として利用頻度につ いても5段階で聞いた. 弚の結果, 総合満足度の「不 満」評価と，利用頻度の「ほとんど利用なし」のサンプ ルか非常に少なくなったため, ここでは総合満足度の5 段階評価を,「満足」「やや満足」評価を「満足」とし て,「やや不満」「不満」評価を「不満」として3段階 で集計し直した . 利用頻度も「ほぼ毎日」「週3〜4 日」を「高頻度」として，「週1〜2日」を「中頻度」 として，「月数回」「ほとんと利用なし」を「低頻度」 として3段階で集計し直した .

图 2 は,コミュニティバスごとの, 利用頻度別の総 合満足度の割合である . 総合満足度と利用頻度に直接的 な関係がある場合, 高頻度利用者の総合満足度は高く， 低頻度利用者の総合満足度は低くなると想定されるが， 図では「じゅんかい君」の高・中頻度利用者において満 足割合か高くなったものの, 中・低頻度利用者は高頻度
表 3 アンケート配布・回収結果

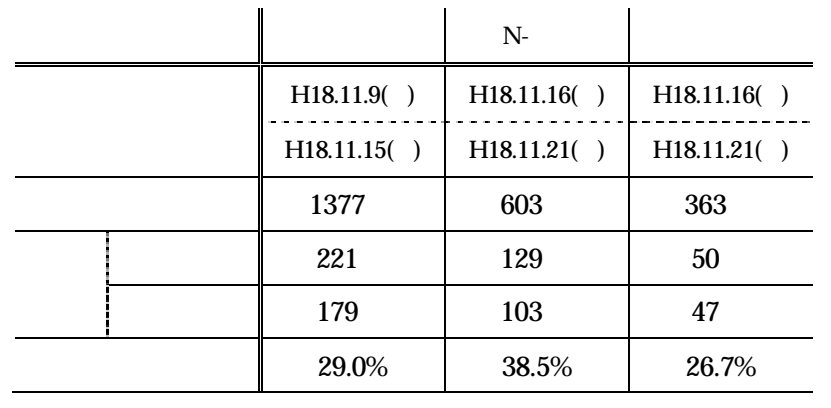

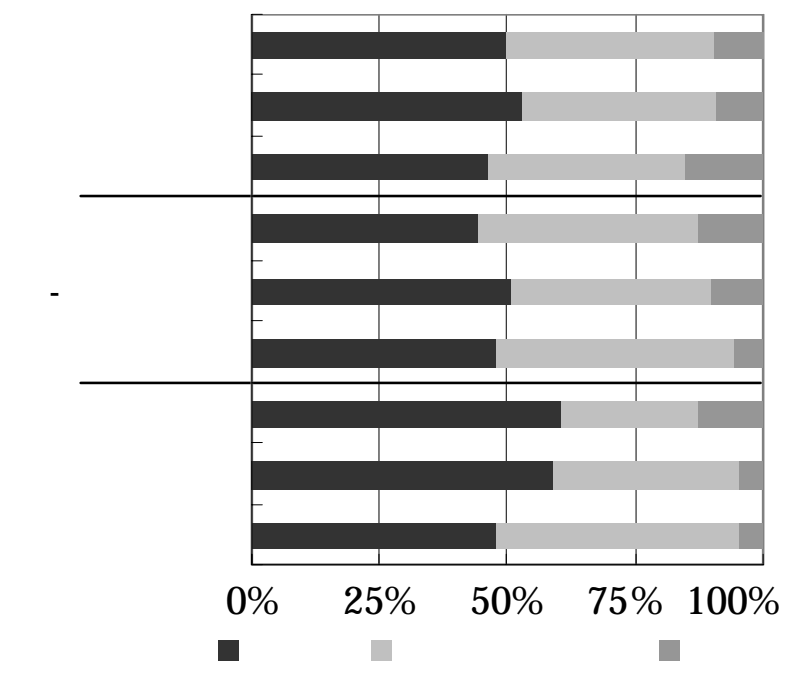

図 2 コミュニティバス別の満足度と利用頻度

表4 満足度・頻度別の利用者分布

\begin{tabular}{|c|c|c|c|c|}
\hline & \multirow{3}{*}{ 満足 } & \multirow{3}{*}{$\begin{array}{c}\text { どちらで } \\
\text { もない }\end{array}$} & \multirow{3}{*}{$\begin{array}{l}\text { 不満 } \\
3.4 \%\end{array}$} \\
\hline & & & & \\
\hline \multirow{3}{*}{$\begin{array}{l}\text { 高 } \\
\text { 齢 } \\
\text { 者 }\end{array}$} & 高頻度 & & & \\
\hline & 中頻度 & $14.5 \%$ & $13.6 \%$ & $3.4 \%$ \\
\hline & 低頻度 & $10.8 \%$ & $11.1 \%$ & $2.3 \%$ \\
\hline \multirow{3}{*}{$\begin{array}{l}\text { 非 } \\
\text { 高 } \\
\text { 齢 } \\
\text { 者 }\end{array}$} & 高頻度 & $18.4 \%$ & $13.9 \%$ & $5.7 \%$ \\
\hline & 中頻度 & $14.4 \%$ & $7.5 \%$ & $1.5 \%$ \\
\hline & 低頻度 & $18.4 \%$ & $15.4 \%$ & $4 . .8 \%$ \\
\hline
\end{tabular}

利用者に対して不満割合か低くなっている．「くるりん ばす」，「N-バス」の利用頻度別では, 総合満足度は どれも同じような割合となった .このことから，各コミ ユニティバスともに, 総合満足度は必ずしも利用頻度に は影響しないことが考えられる。

各コミュニティバス間に大きな差異がかったため， ここからは各コミュニティバスの利用者意識調査結果を 集計して扱う.

表 4 は, 全コミュニティバスの総合満足度と利用頻 度別の利用者分布状況である . 高 - 中頻度利用者と共に 低頻度利用者も多く含まれていることから，日常の利用 者に加え，普段はあまり乗車しない利用者の意識も反映 されていると考えられる . 
前述と同樣に, 総合満足度と利用頻度に直接的な関 係があると仮定した場合, 不満て低頻度の利用者は, 総 合満足度力不満から満足へと変化するにつれて, 利用頻 度も低頻度から高頻度へと向上するといった効果か考え られるため, 表の灰色て示した対角線上に多くの利用者 が分布することが予想される.しかしながら，実際の利 用者分布を見ると, 高齢者, 非高齢者ともに, 全ての利 用頻度において「満足」もしくは「どちらでもない」と 回答した割合が多く、「低頻度」で「不満」の利用者は 少ないことが分かる.これらより, 総合満足度と利用頻 度には直接的な関係はないといえる。

\section{4. 利用者の総合満足度と利用頻度に影響する要因の差} 異の把握

次に，利用者の総合満足度と利用頻度に光れ影 響する要因と光の差異を明らかにする.本研究ては，利 用者の特徵を表す指標として, コミュニティバス利用者 の利用形態と，運行サービス 17 項目への満足度評価を 取り上げる. 光して, 総合満足度・利用頻度との相関関 係を把握するため, カテゴリカル正準相関分析 9) を行 い, 利用者像を明らかにする.このカテゴリカル正準相 関分析は, 質的データを対象とした正準相関分析で, カ テゴリカル回帰分析やカテゴリカル主成分分析を含んだ 一般型となっている.なお，ここからはサンプル数の都 合上, 総合満足度のうち, 「どちらでもない」と「不 満」をあわせ「不満」と区分し, 総合満足度 2 区分と 利用頻度 3 区分て分析を行う。

\section{(1) 利用形態との関係}

コミュニティバス利用者の利用形態として , 利用時 間帯, 1 日の乗車回数, 利用目的, 乗車距離の 4 項目を 取り上げる.利用時間帯は, 朝, 昼, 夜の三区分とし, 1 日の乗車回数は, 1 回のみの場合と複数回の二区分と した. 利用目的は, 通勤・通学, 通院・検診, 業務, 買 物 , 私用の五区分である.乗車距離はバス停 10 区間以 内のものを短距離とし，11区間以上を長距離とした .

高齢者における総合満足度 ·利用頻度と利用形態 4 項目とのカテゴリカル正準相関分析の結果のうち, 1 次 元のカテゴリ数量を横軸に, 2 次元を緷軸に取って, 弚 れ光れの要因のカテゴリごとにプロットしたものを図 3 に示す .この図から , 各要因のカテゴリ間の関係を読み 取ることができ，相対的に近いところに位置するカテゴ リ間の関連力強いと言える．なお，相対的な位置関係を 分かりやすく表現するため, 利用形態項目は座標值を 2

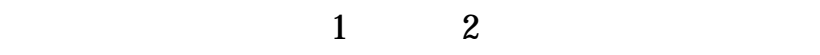
れ 0.81 と 0.79 となり，この 2 次元て約 80\%の情報を 捉えることができた .

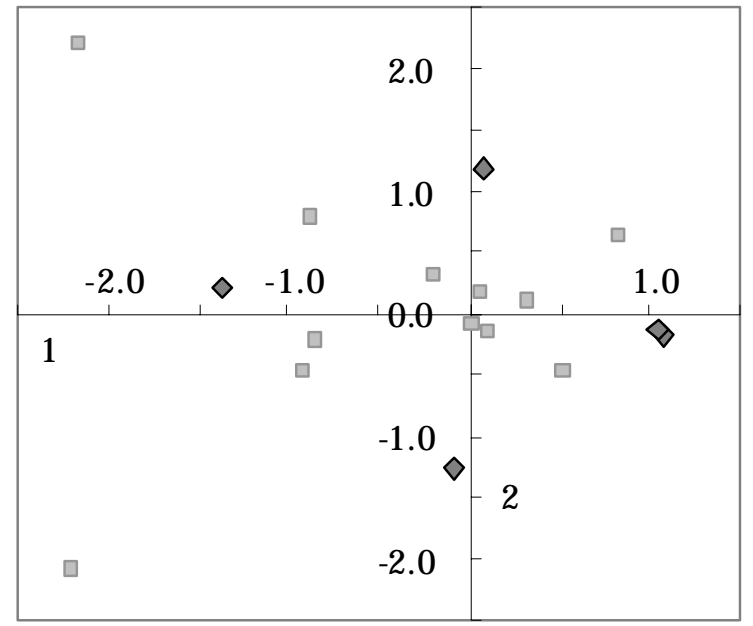

図3 満足度・頻度と利用形態の関係 (高齢者)

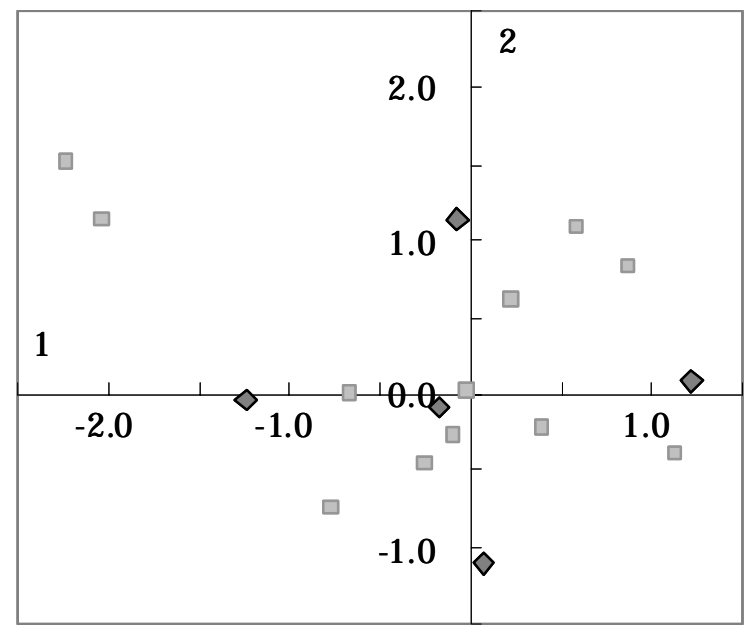

図4 満足度・頻度と利用形態の関係 (非高齢者)

図より, 高頻度と通勤, 朝, 複数回の座標力゙近い位 置にあることから, 高頻度利用者は通勤・通学目的利用 が多いことが分かる.また，朝時間帯と，1 日に複数回 バスを利用していることが分かる.中頻度・低頻度利用 者は, 私用目的での利用や, 昼時間帯, 1 日あたり 1 回 のみの利用者が多いことが分かる.このことから，仮に 高齢者の利用頻度を増加させるには，私用目的などの非 定期利用者の増加を図る必要があるといえる．また，高 頻度利用者は朝時間帯利用者が多く, 中頻度・低頻度利 用者は昼時間帯利用者に多いことから，昼時間帯の利用 促進を図るなどの時間帯を絞った対策も有効であるとい える。

図 4 は, 非高齢者における利用者満足度・利用頻度 と利用形態 4 項目のカテゴリ数量をプロットしたもの である . 同樣に , 利用形態項目は座標值を 2 倍して表 示している. 1 次元と 2 次元の固有值は乥れ光れ 0.81 と 0.72 となり，この 2 次元て約 76\%の情報を捉えるこ とができた .

図より，高頻度利用者は通勤・通学目的利用が多い ことが分かる.一方, 中頻度・低頻度利用者は, 買物目 
的，私用目的での利用や，1 日あたり 1 回のみの利用 が多いことか分かる.このことから, 非定期利用者の増 加施策は高齢者とともに非高齢者にも有効な施策である といえる．

また, 満足利用者は昼時間帯利用者が多く, 不満利 用者は朝時間帯と夜時間帯利用者, 複数回利用者に多い ことが分かる.このことから, 朝時間帯と夜時間帯を対 象とした満足度向上施策では, 非高齢者の満足度向上に 有効であると考えられる .

\section{(2) 運行サービスとの関係}

次に, 総合満足度と利用頻度に光れ影響する運 行サービス項目と谷の差異を明らかにする.調査では， 総合満足度とともに, 表 5 に示した運行サービス 17 項 目についても満足度を評価してもらつた . 分析では総合 満足度と同樣に 2 段階て集計し直して使用する. 運行 サービスの表記は，表5の略記を用いる .

图 5 は, 高齡者における総合満足度・利用頻度と運 行サービス 17 項目のカテゴリ数量をプロットしたもの である .なお，相関関係を分かり易く表現するため, 運 行サービス項目は座標值を2 倍して表示している. 1 次 元と 2 次元の固有值は光れ光れ 0.91 と 0.76 となり，こ の2 次元て約 83\%の情報を捉えることができた .

図より，高頻度利用者は「一周」に満足している一 方，「運転」「定時」に不満を持っていることが分かる． 中頻度・低頻度利用者では逆の利用者像となり，「一 周」に不満を持っている一方，「時間」「運転」「定 時」に満足していることが分かる.これは, 時間・運 転・定時に満足すると利用頻度か低下するという意味で は無く, 利用頻度の少ない高齢利用者は, コミュニティ バスの運行時間帯に主に外出する私的目的利用者が多い ことにより，時間にも満足していると考えられる．また， 運転や定時の影響を受けにくいと考えられる．つまり， 利用頻度の低い利用者以外では, 運転や定時に不満を感 じていると捉えることもできる .

満足利用者は, 「本数」と「位置」「運賃」に満足 していることが分かる. 不満利用者は, 「運賃」に不満 を持っていることが分かる.

図 6 は, 非高齢者における総合満足度・利用頻度と 運行サービス 17 項目のカテゴリ数量をプロットしたも のである . 同樣に , 運行サービス項目は座標值を 2 倍 して表示している . 1 次元と 2 次元の固有值は光れ光れ 0.85 と 0.67 となり，この 2 次元て約 76\%の情報を捉え ることができた .

図より，高頻度利用者は「案内」や「位置」に満足 していることか分かる.一方, 中頻度・低頻度利用者で は「案内」「位置」に不満であり，「時間」「心地」 「施設」に満足していることが分かる.これは, 高齢者
表 5 運行サービス評価項目

\begin{tabular}{c|l|l} 
& \multicolumn{1}{|c|}{ 評価項目 } & 略記 \\
\hline \hline (1) & バスの経路 & 経路 \\
\hline (2) & コースの循環形態 & 循環 \\
\hline (3) & 役所や役場, 福祉の家に発着 & 発着 \\
\hline (4) & バスの本数 & 本数 \\
\hline (5) & 運行時間帯 & 時間 \\
\hline (6) & コースの1周にかかる時間 & 周 \\
\hline (7) & 自宅から最寄りバス停の距離 & 最寄 \\
\hline (8) & バス停から目的地までの距離 & 目的 \\
\hline (9) & バス停の位置 & 位置 \\
\hline (10) & バスの定時性 & 定時 \\
\hline (11) & バス停の施設 & 施設 \\
\hline (12) & バスへの乗降のしやすさ & 乗降 \\
\hline (13) & バスの乗り心地 & 心地 \\
\hline (14) & バスの外観・デザイン & 外観 \\
\hline (15) & バス運転手の対応 & 運転 \\
\hline (16) & バスス車内案内 & 案内 \\
\hline (17) & 運賃 & 運賃 \\
\hline
\end{tabular}

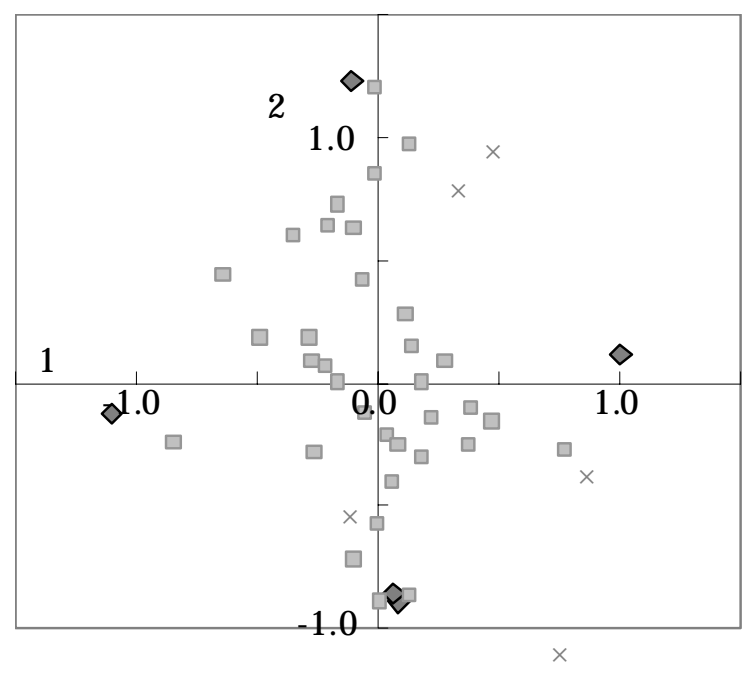

图 5 満足度・頻度と運行サービスの関係 (高齢者)

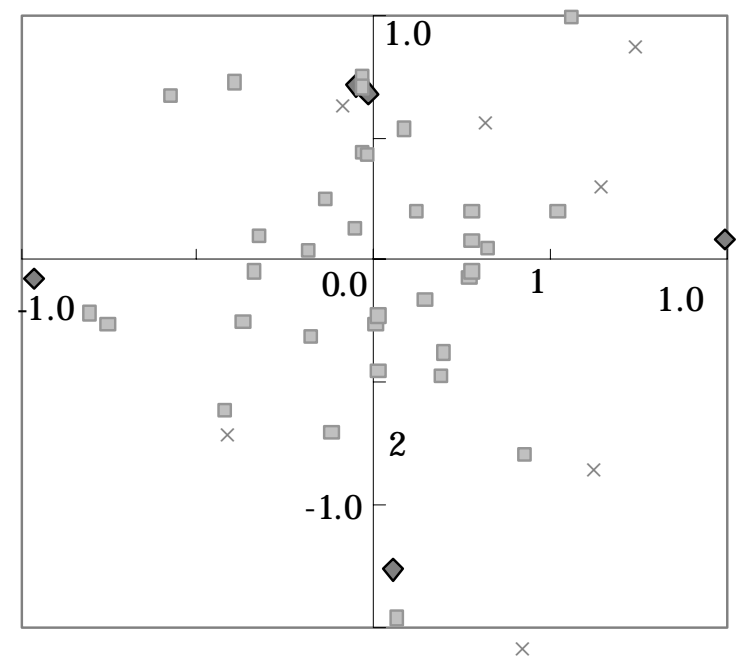

図 6 満足度・頻度と運行サービスの関係 (非高齢者) 
同樣，私的目的利用者が多いことか影響していると考え られる．また，利用頻度の低い利用者以外では，「心 地」や「施設」に不満を感じていると捉えることもでき る。

満足利用者は，「一周」と「経路」に満足している ことが分かる、不満利用者は, 「経路」に不満を持って いることが分かる。

\section{5. 運行サービスに対する評価の感度分析}

次に, 運行サービスに対する評価の改善が, 利用者 満足度と利用頻度にどのように影響するのかを見るため， 分析結果から得られた総合満足度・利用頻度と運行サ一 ビス 17 項目の相関関係を表すモデルを用いて, 感度分
析による個々の運行サービス項目か改善された場合の評 価を想定したシナリオ分析を行う.なお，本研究に用い たモデルのパラメタとなる 1 次元成分負荷量とカテゴ

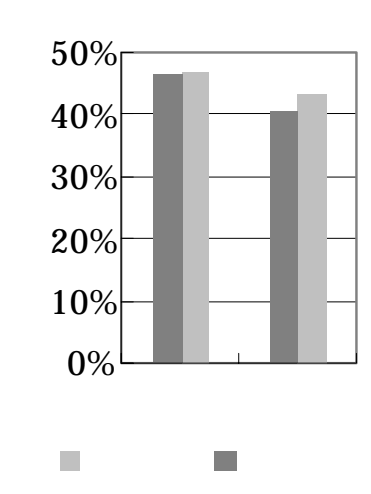

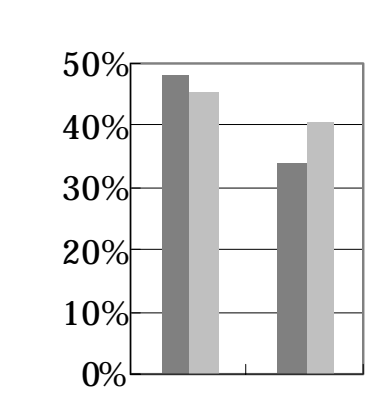

満足 高頻度

推定値 実績值

図 7 現況再現

表 6 満足度・頻度と運行サービスの 1 次元成分負荷量・カテゴリ数量

\begin{tabular}{|c|c|c|c|c|c|c|c|c|c|c|c|c|c|c|c|}
\hline \multirow[t]{3}{*}{ 属性 } & \multicolumn{4}{|c|}{ 高齢者 } & \multicolumn{4}{|c|}{ 非高齢者 } & \multicolumn{4}{|c|}{ 高齢者 } & \multicolumn{3}{|c|}{ 非高齢者 } \\
\hline & \multirow{2}{*}{$\begin{array}{l}\text { 成分負 } \\
\text { 荷量 }\end{array}$} & \multicolumn{3}{|c|}{ カテゴリ数量 } & \multirow{2}{*}{$\begin{array}{c}\text { 成分負 } \\
\text { 荷量 }\end{array}$} & \multicolumn{3}{|c|}{ カテゴリ数量 } & & \multirow{2}{*}{$\begin{array}{l}\text { 成分負 } \\
\text { 荷量 }\end{array}$} & \multicolumn{2}{|c|}{ カテゴリ数量 } & \multirow{2}{*}{$\begin{array}{c}\text { 成分負 } \\
\text { 荷量 }\end{array}$} & \multicolumn{2}{|c|}{ カテゴリ数量 } \\
\hline & & 高頻度 & 中頻度 & 低頻度 & & 高頻度 & 中頻度 & 低頻度 & & & 満足 & 不満 & & 満足 & 不満 \\
\hline \multirow[t]{4}{*}{ 利用頻度 } & 0.19 & -1.18 & 0.84 & 0.84 & -0.09 & -1.35 & 0.74 & 0.74 & 最寄 & 0.27 & -0.76 & 1.84 & 0.19 & -0.61 & 2.01 \\
\hline & & & & & & & & & 目的 & 0.47 & -1.33 & 1.06 & 0.51 & -1.12 & 1.06 \\
\hline & \multirow{2}{*}{$\begin{array}{l}\text { 成分負 } \\
\text { 荷量 }\end{array}$} & \multicolumn{2}{|c|}{ カテゴリ数量 } & & \multirow{2}{*}{$\begin{array}{c}\text { 成分負 } \\
\text { 荷量 }\end{array}$} & \multicolumn{2}{|c|}{ カテゴリ数量 } & & 位置 & 0.58 & -1.58 & 0.94 & 0.42 & -1.26 & 0.95 \\
\hline & & 満足 & 不満 & & & 満足 & 不満 & & 定時 & 0.50 & -1.24 & 1.17 & 0.34 & -1.19 & 0.99 \\
\hline 忩合満足 & 1.06 & -1.04 & 0.96 & & 0.98 & -0.99 & 1.01 & & 施設 & 0.45 & -1.74 & 0.80 & 0.43 & -1.52 & 0.79 \\
\hline 経路 & 0.57 & -1.65 & 0.87 & & 0.58 & -1.31 & 0.91 & & 乗降 & 0.49 & -0.84 & 1.53 & 0.44 & -0.87 & 1.35 \\
\hline 循環 & 0.48 & -2.19 & 0.64 & & 0.38 & -2.14 & 0.55 & & 心地 & 0.46 & -1.10 & 1.30 & 0.34 & -1.05 & 1.13 \\
\hline 役所 & 0.58 & -0.86 & 1.53 & & 0.42 & -1.26 & 0.95 & & 外観 & 0.43 & -1.19 & 1.23 & 0.31 & -0.87 & 1.35 \\
\hline 本数 & 0.55 & -2.07 & 0.70 & & 0.47 & -2.16 & 0.55 & & 運転 & 0.45 & -1.06 & 1.41 & 0.50 & -1.04 & 1.15 \\
\hline 時間 & 0.42 & -1.41 & 1.02 & & 0.48 & -1.82 & 0.65 & & 案内 & 0.53 & -1.62 & 0.85 & 0.34 & -1.57 & 0.75 \\
\hline 一周 & 0.48 & -1.70 & 0.81 & & 0.54 & -1.86 & 0.64 & & 運賃 & 0.55 & -0.98 & 1.55 & 0.44 & -0.62 & 1.93 \\
\hline
\end{tabular}

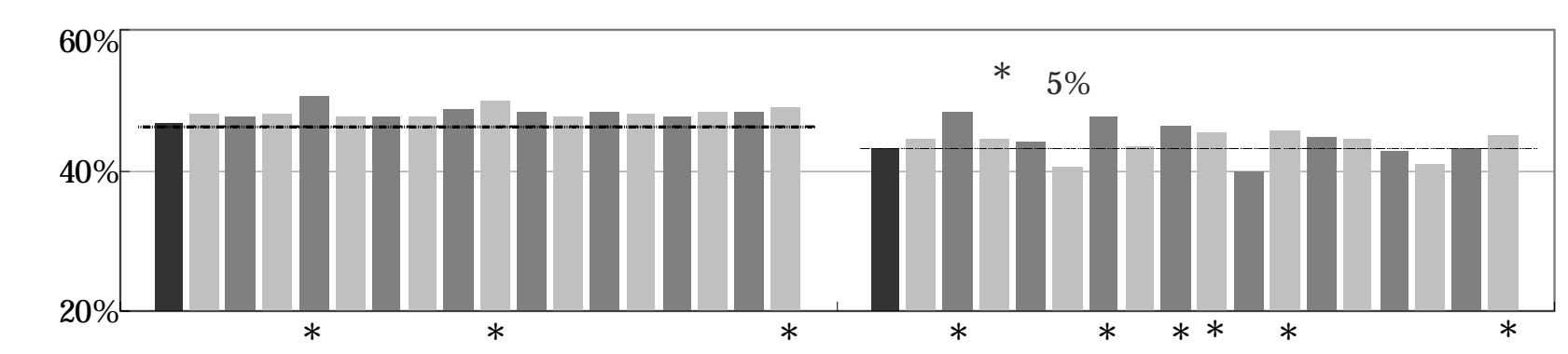

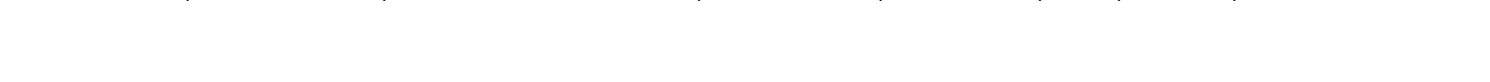
<

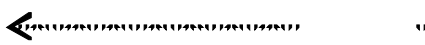

図 8 運行形態の改善効果 (高齢者)

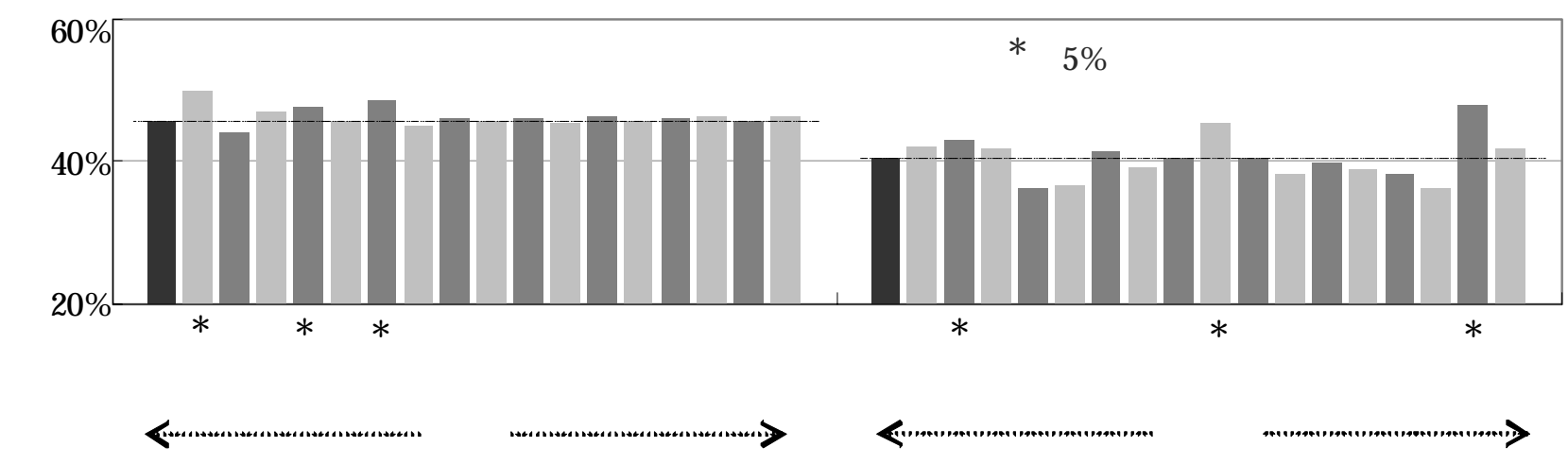

図 9 運行形態の改善効果 (非高齡者) 
リ数量を表 6 に示す.

平成 17 年に日進市「くるりんばす」において運行サ 一ビスの改善か行われた事例ては, 運行サービス項目に 対する満足評価割合が最大で 20\%増加したという結果 か得られている 8). 乥こで本研究では, 想定するシナリ オとして, 運行サービス 17 項目の兰れ光れの満足評価 割合が，20\%増加した場合を考え，総合満足度と利用頻 度に及ぼす影響を捉える、なお，運行サービスとの関係 分析において, 利用頻度のうち「中頻度」と「低頻度」 がほほ同じ值となったため，ここからは合わせて「低頻 度」とし, 総合満足度 2 区分と利用頻度 2 区分て分析 を行う。

はじめに現況再現を行った .結果を図 7 に示す.総 合満足度と利用頻度を集計した值力実績値で, 運行形態 17 項目のパラメータから算出した值か推定值である . 高齢者の推定精度は, 総合満足度が $100.6 \%$, 利用頻度 が 106.3\%となった . 非高齢者の推定精度は, 総合満足 度が $94.4 \%$, 利用頻度が 118.6\%となり，非高齢者の利 用頻度の誤差は大きめであるが , 概ね現況か再現できて いる。

この推定值を用いて, 各運行サービス評価項目につ いてシナリオ分析を行った . 評価か改善された場合の総 合満足度と利用頻度の推定値について, 高齢者を図 8 に, 非高齢者を図 9 に示す。

弚れ光れ一例として 5\%以上の改善効果力認められた 項目を取り上げると, 高齢者の総合満足度向上には「本 数」「位置」「運賃」の改善が, また利用頻度向上には

「循環」「一周」「目的」「位置」「施設」「運賃」の 改善力効果的であることが分かった . 非高齡者の総合満 足度向上には「経路」「本数」「一周」の改善が，また 利用頻度向上には「循環」「位置」「案内」の改善力効 果的であることが分かった .

「循環」では, 高齢者と非高龄者の利用頻度に改善 効果があることが分かった . 谷の評価の詳細を見ると， 東郷町「じゅんかい君」への評価か高いことから，产の 循環形態である双方向運行か頻度向上へ寄与することが 考えられる.「本数」では, 高龄者と非高龄者の総合満 足度に改善効果があることが分かった .これは, 運行本 数の増加による乗車機会の拡大は利用者に歓迎されるが， 利用者は現状の運行本数を前提に行動しており, 利用の 拡大にはつながらないことが考えられる．「一周」で， 高齢者ては利用頻度に, 非高齢者で総合満足度に改善 効果があることが分かった .これは, 高齢者の平均乗車 距離が, 非高齢者に比へ長いことか影響していると考え られる. 非高齢者では, 所要時間の短縮効果を評価して いると考えられる。「目的」ては，高齢者の利用頻度に 改善効果があることが分かった．また，「位置」では， 高齢者の総合満足度と利用頻度の双方に, 非高齢者の利
用頻度に改善効果があることが分かった .このことから， バス停から目的地までイグレス距離か重要視されてい ることが考えられる。ただし，非高齡者の総合満足度で は，イグレス距離の短縮よりも「経路」の改善効果か高 い.コミュニティバスの「施設」では, 高齢者の利用頻 度に改善効果があることが分かった .これは, 高齢者に とってバス停で待ち時間が負担になっていることが考 えられる。「案内」では, 非高齢者の利用頻度に改善効 果があることが分かった .これは, 非高齢者では高齢者 に比べ低頻度利用者が多いことから，不慣れなコミュニ ティバスを利用するにあたって，多くの情報を必要とし ているからだと考えられる．「運賃」では，高龄者の総 合満足度と利用頻度に改善効果があることが分かった 。 これは，長久手町「N-バス」と東郷町「じゅんかい 君」では高龄者運賃無料施策が行われており，日進市

「くりんばす」においても高齢者定期券力発行される など優遇措置か取られていることが，高龄者の利用を促 し評価を高めていると考えられる .

なお，一部の項目において，満足割合が低下したり， 高頻度割合が低下する結果となった ，一例として高龄者 の「時間」に対する評価に着目すると，第 4 章て述べ たように，利用頻度の少ない高齢利用者はコミュニティ バスの運行時間帯に主に外出する私的目的利用者が多く， 結果的に「時間」にも満足していると考えられる．つま り，不満や低頻度であっても，現状に不満を感じていな い利用者が多い項目は, シナリオ分析では正しく変化を 捉えられないと考えられる。

\section{6. おわりに}

本研究では, より良いコミュニティバスの検討に資 する知見を得るため, 愛知県日進市, 長久手町, 東鄉町 の 3 市町て運行されているコミュニティバスの利用者 を対象にアンケート調査を実施し，利用形態や利用者意 識の分析を行った .

コミュニティバスの評価指標の一つである利用者の 総合満足度は, 一般的に, 改善によって利用頻度の向上 にもつながると考えられているが, 総合満足度と利用頻 度の関係について見たところ，この 2 者には直接的な 関係はないことが分かった .

次に, 総合満足度と利用頻度に影響する要因の差異 を把握するため, 各種指標とのカテゴリカル正準相関分 析を行った . 兴の結果, 総合満足度と利用頻度別によっ て, また，属性別によっても利用者像がきき異なるこ とが分かった .この結果, 利用者のコミュニティバスに 対する評価も大きく異なってくると考えられ，よりよい 運行サービスを検討する上で, 属性ごとの的確な利用者 意識の把握が必要であると考えられる。 
次に, 個々の運行サービス評価項目に対する満足度 評価力改善された場合の, 総合満足度と利用頻度に及ぼ す影響を捉えるため, シナリオ分析を行った . 兴の結果， 総合満足度と利用頻度で改善に必要な施策か潩なるこ とが分かった . また, 属性によって改善に有効な施策が 異なることが分かった . 今後, 属性別の改善効果の差異 を考慮することも，より良いコミュニティバス運行サー ビスを検討する上で重要である .

本研究では,コミュニティバス利用者を調査対象と し，現利用者の総合満足度と利用頻度向上施策の提案を 行った . しかしながら, 現状の利用者意識や実態に基づ いたものであつたため, 今後の課題として, 運行サービ 不改善の前後て調査を行うなど, 実際の变化力総合満足 度，利用頻度に及ぼす影響を直接的に把握する必要があ る.また, シナリオ分析を行う際にも, 変化に基ついた モデルを用いることにより，満足度か高いにも関わらず 低頻度利用の人たちの行動变化を的確に表現し,より実 現に可能な対策へ結びつけることか望まれる.さらに， 利用者の純増を検討する場合には, 非利用者の利用しな し理由などを調べる必要がある。

\section{謝辞}

本研究に取り組むにあたり，調査の実施やデータの提供で日 進市防災安全課, 長久手町安心安全課, 東鄉町財政課の方々に 快くこ協力いただいた．ここに記して謝意を表します．

\section{参考文献}

1) 国土交通省中部運輸局 : 中部におけるコミュニティバス の現状と課題 , 2008

2）樋口民夫，秋山哲男 : コミュニティバス計画のサービス 水準の評価に関する研究, 第 35 回日本都市計画学会学術 研究䆚文集, pp.517-522, 2000

3）板谷和也, 橋本成仁, 小倉俊巨, 山崎基浩 : 公共交通試 験運行における利用者意識の経年変化一尾張旭市を事例 として一, 第 27 回交通工学研究発表会論文報告集, pp.145-148, 2007

4）井上佳和, 松本幸正, 松井寛 : コミュニティバスの利用 者属性に基づく利用実態と利用者意識の分析一愛知県日 進市「くるりんばす」をケーススタディとして一，第 40 回日本都市計画学会学術研究侖文集, pp.319-324, 2005

5）中村文彦 : コミュニティバスの導入ノウハウ, 現代文化 研究所, 2006

6) 鈴木文彦, 寺田一薰: 改正道路運送法:新・乗合事業編 バ ス・タクシーの地域・住民ニーズ 中間モード・システム と新市場一新しい事業区分と地域公共交通の構築:実践・ 実務資料集, 地域科学研究会, 2006

7）榊原充輝，松本幸正：利用者属性に着目したコミュニテ イバス利用者満足度向上施策に関する一考察，土木学会 全国大会, 第63回年次学術講演会講演概要集, 2008

8）井上佳和，松本幸正：コミュニティバスの運行形態変更 に伴う利用実態と利用者意識の変化に関する研究〜愛知 県日進市「くるりんばす」をケーススタディとして〜， 土木学会全国大会, 第 61 回年次学術講演会講演概要集, 2006

9) SPSS : SPSS Statistics 17.0 Manuals, CD-ROM , SPSS , 2008

利用者属性に着目したコミュニティバス利用者満足度と利用頻度向上施策に関する研究*

神原充輝**・松本幸正***・高橋政稔****

本論文ては, より良いコミュニティバスの検討に資する知見を得ることを目的とし，愛知県日進市，長久 手町, 東郷町の 3 市町て運行されているコミュニティバスを対象として , 利用者意諳調査を実施した . 一般 的に, 利用者の満足度向上は利用頻度の向上につながると考えられているが, 利用者満足度と利用頻度の関 係について見たところ，この2 者には直接的な関係はないことが分かった . 次に , 利用者満足度と利用頻度 別の利用者像を明らかにするため，カテゴリカル正準相関分析を行った .ここから得られた指標を用いて， 運行形態に対する改善効果を分析した結果, 利用者満足度と利用頻度では改善に必要な施策か潩なることが 分かった .また , 属性によって改善に有効な施策か潩なることが分かった .

\section{I mprovement measures of operation on community bus considering passenger attributes*}

By Mitsuteru SAKAKIBARA** • Yukimasa MATSUMOTO*** • Masami TAKAHASHI ****

In order to grasp the improvement effect of bus operation, passenger consciousnesses were investigated on the community buses operated in Nisshin City, Nagakute Town, Togo Town, Aichi prefecture. In general, it is thought that the degree of satisfaction relates to the frequency of using the community bus. However, we have not seen the relation directly between the satisfaction and the frequency. The improvement effect of bus operation was grasped under simulated scenarios. As a result, it is clarified that the bus operation to improve the satisfaction is different from the operation to increase the frequency, and effective measures to improve the satisfaction or the frequency depend on the passenger attributes. 